\title{
INTEGRATED MELIORATION MEASURES ON RESTORATION OF POLLUTED AND DEGRADED SOILS FERTILITY
}

Yuri MAZHAYSKY, Russian Scientific-Research Institute of Hydrotechnyc and Melioration, Meshersky branch, Ryazan,Tipanova str. 7, 390013, Russia, mail@mntc.pro (corresponding author)

Tatyana GUSEVA, Microbiology Department, Ryazan State Medical University named after academician I.P. Pavlov, ul. Moscow highway 39-4/29, Ryazan, Russia, guseva.tm@yandex.ru

Otilija MISECKAITE், Institute of water resources engineering, Water and Land Management Faculty, Aleksandras Stulginskis

University, Studentu g. 10, LT-53361 Akademija, Kaunas, Lithuania, otilija.miseckaite@asu.It

In case of significant technogenic geochemical loads on agricultural landscapes, the issue of ecological forecasting of environmental management is particularly important. Scientific studies of this issue are aimed at establishing the critical values for the components of the ecosystem, the classification of technogenic sources of hazardous substances, levels of soil contamination. This study presents a research to determine the content of heavy metals in the soils of the Ryazan region (Russia) and analyzed the level of their pollution. In the experiments organic, organomineral and mineral fertilizers systems were studied. From 2002 to 2008 were conducted lysimetric experiments on detoxification of elevated pollution of sod-podzol sandy loam soil, and from 2006 to 2008 of podzolized black soil. The participation of the non-ferrous metals plant emissions was detected in the pollution of sod-podzol light in granulometric composition soils with copper of up to $80 \mathrm{mg} \cdot \mathrm{kg}^{-1}$, when the average concentration of $\mathrm{Cu}$ in the soil was $38.8 \pm 6 \mathrm{mg} \cdot \mathrm{kg}^{-1}$. $\mathrm{Humification}$ plays a significant role in the formation of soil, its most important properties and characteristics. The saturation of 1 hectare of sown area with organic was slightly different in the experiments, but the intensity of accumulation of humus from the various agrochemical means did not almost differ. The problem of adaptation of plants in the conditions of technogenic environment is of primary importance. Plants have three biobarera against the admission of toxicants, these are the soil - the root - the stem - the reproductive organs. Grain in contaminated soil is environmentally hazardous as the content of $\mathrm{Pb}$ is indicated at the level of $0.68,1.17 \mathrm{mg} \cdot \mathrm{kg}^{-1}(\mathrm{MPC} 0.5)$, $\mathrm{Cd}-0.27,0.11 \mathrm{mg} \cdot \mathrm{kg}^{-1}$ (MPC 0.1), $\mathrm{Zn}-76 \mathrm{mg} \cdot \mathrm{kg}^{-1}$ (50 MPC). Use of fertilizing systems had a mostly positive effect, but products do not always become environmentally friendly.

Keywords: degraded soil, environmental monitoring, fertilizers, heavy metals, melirationtion, soil detoxification

\section{INTRODUCTION}

Soil and water microorganisms play an important role in maintaining ecosystem environmental quality. In fact, the ability of soil and water to recover from chemical contamination is primarily dependent on the presence of a microbial community with the ability to remove it. In this way, the microbial community represents an important key to understanding the impacts of environmental and anthropogenic factors on ecosystems. The presence of an abundant and varied microbial community is a necessary prerequisite for an immediate and effective response to the various natural and anthropic disturbances that can affect an ecosystem (Caracciolo et al., 2013). Agricultural intensification invariably has several negative impacts on the environment (Cerri et al., 2007). The deterioration of soil quality/health is the combined result of soil fertility, biological degradation (decline of organic matter, biomass $\mathrm{C}$, decrease in activity and diversity of soil fauna), increase in erodibility, acidity, and salinity, and exposure of compact subsoil of poor physicochemical properties (Saha et al., 2012). In recent years, increasingly more soils are found to be contaminated with organic and inorganic toxins globally due to waste emissions from industrial production, mining activities, waste (i.e., biosolids and manures) application, wastewater irrigation, and inadequate management of pesticides and chemicals in agricultural production (Bolan et al. 2004; Mclaughlin et al.,1999; Mench et al. 2010). Soil contamination with heavy metals and organic pollutants has increasingly become a serious global environmental issue in recent years. Considerable efforts have been made to remediate contaminated soils (Zhang et al., 2013). Soil pollution is an increasing concern in many countries worldwide due to the detrimental short-term and long-term effects on humans, other life-forms and the environment (Venny et al., 2012). Soil metal-pollution as consequence of mining activities and/or other industrial activities represent a potential hazard for living organism due to high bioavailability of metals (Tordoff et al., 2000). The application of different soil organic and/or inorganic amendments may play a key role in governing the mobility of metals

Copyright (C) 2015 The Authors. Published by Aleksandras Stulginskis University. This is an open-access article distributed under the terms of the Creative Commons Attribution License (CC-BY 4.0), which permits unrestricted use, distribution, and reproduction in any medium, provided the original author and source are credited. 
in soil and, for thus, reducing metals' availability and toxicity for plants and microorganisms (Janos et al., 2010). According to the estimate made by (Neustadt, 1984), on the territory of Russia the mean polludification rate for the entire Holocene was 15 thou ha per year, whereas our estimates (Kobak et al., 1998) indicate 18 thou ha per year. The concentration of metals in atmospheric precipitations, of both warm and cold periods, varies in periods and years (Evtyuhin, 2011). Heavy metals, received from the atmosphere, is included in the biogenic migration of water, are accumulated in the soil cover are included in a large-scale geological circulation. The total content of HM in natural unpolluted soils is due to their concentration in the soil-forming rocks and is defined by genesis, mineralogical composition of fine particle fractions, facial differences of the mother understratum substrate and soil-forming processes. (Ovcharenko, 1997). The soil inherits its mineralogical composition (geochemical background) from the soil-forming rock. Therefore, for the environmental assessment of soil contamination, their gradation on the gross (average) content of elements-contaminants in the soil-forming rock, was developed, which implies regional background of heavy metal. Regional soil-forming rocks concentrated: $\mathrm{Pb} \quad 8-16 \mathrm{mg} \cdot \mathrm{kg}^{-1}, \mathrm{Cd} \quad 0.15-0.29 \mathrm{mg} \cdot \mathrm{kg}^{-1}, \mathrm{Zn} 33-46 \mathrm{mg} \cdot \mathrm{kg}^{-1}, \mathrm{Cu}$ 20.9-27.0 mg $\cdot \mathrm{kg}^{-1}$. (Mazhaysky, 2002). Soil microorganisms can affect trace metal mobility and availability to the plants (Abou-Shanab et al., 2003; Idris et al., 2004). For example, the presence of rhizosphere (defined as the volume of soil adjacent to and influenced by the plant root) (Smalla et al., 2001) bacteria increased the uptake of Cd in Brassica napus (Sheng and Xia, 2006).

\section{MATERIALS AND METHODS}

From 2002 to 2008 was conducted lysimetric experiments on detoxification of elevated pollution of $(\mathrm{Pb}, \mathrm{Cd}, \mathrm{Zn}$, $\mathrm{Cu}$ ) sod-podzol sandy loam soil, and from 2006 to 2008 of podzolized black soil in Ryazan region, Russia. The dynamics of the behavior of contaminants in the soil leads to their accumulation or removal from the soil profile. The main types of soils: black soils, grey forest soils, sod-podzol soils and alluvial soils. Research conducted in two stages, allowed to clarify and confirm the idea of the association of chemical contaminant elements by the statistical calculations. In the experiments, organic, organomineral and mineral fertilizers systems were studied: field No. 1 - control, field No. 2 - H40 N1P1K1, field No. 3 - H40 P1K1 P2, field No. 4 - H40 P1K1 P4, field No. 5 - H80, field No. 6 - P480 N1K1. Diagram of an experiment suggests the studies of contaminated soil productivity (field No. 1). In the fields No. 2, 3, 4, 5, manure of cattle (H40) was applied only 2 times for crop rotation (for row crops). Mineral fertilizers (optimal doses of N1P1K1) in the second field were used annually, except clover. In the fields No. 3 and No. 4, against the backdrop of H40 t/ha $\mathrm{N} 1 \mathrm{~K} 1$, double (P2) and a quadruple (P4) doses of phosphorus were used. In the field No. 5, manure (N80) was used, and in the field No. 6 - N1K1 (annually) R480 - 2 times per crop rotation. The concept of studies is that in agrolandscapes, the presence of not one, but several phytotoxicants is usually observed. Theoretically, in such cases, both strengthening and weakening of the negative effects forces of $\mathrm{HM}$ on individual plants. Scientifically substantiated fertilizers system in the crop rotation certainly has an impact on the complete use of soil nutrients and fertilizers by different crops and its phytosanitary role. The total content of chemical elements in the samples was defined by the spectral method according to the CINAO (Central Research Institute of Agrochemical Service of Agriculture Industry) method using $5 \mathrm{n} \mathrm{HNO}_{3}$ as an extractant. The quantitative determination was carried out in the laboratory of geological and geochemical expedition (Bronnitsy). For this purpose, ICP-MS Elan-6100 ("Perkin Elmer", USA) and atomic emission spectrometer Optima4300 ("Perkin Elmer", USA) were used. The results were processed statistically (least significant difference LSD $_{0.95}$ ).

\section{RESULTS AND DISCUSSION}

Metals, coming out of the atmosphere, to greater or lesser extent are fixed by the soil. Metals fixing speed their mobility mainly depend on the oxidation-reduction conditions prevailing in the soil. A great influence on the intensity of soil contamination is exerted by the proximity of the industrial enterprises. In the alluvial sod-podzol soils, located 5-20 km from Ryazan, the accumulation of $\mathrm{Zn}, \mathrm{V}, \mathrm{Pb}, \mathrm{Cd}$, As at the levels of elevated, medium and low contamination was observed. On average, the soils have low levels of pollution and decrease in the row $\mathrm{Pb}=\mathrm{Zn}>\mathrm{Cd}>\mathrm{Cu}>\mathrm{Mo}+\mathrm{Sn}$ $>\mathrm{Mn}>\mathrm{V}$ in this region. The buffering of soils and the whole ecosystem in relation to the effects of technogenic streams depends on the set of processes that bring excessive destructively active products of technogenesis from the biological circulation (Glazovskaya, 1998). According to the buffering capacity, the best soils of the region are black soils, gray forest soils of heavy granulometric composition formed on the lemons. The sod-podzol soils on fluvioglacial sediments are the least resistant to industrial emissions.

The participation of the non-ferrous metals plant emissions was detected in the pollution of sod-podzol light in granulometric composition soils with copper of up to $80 \mathrm{mg} \cdot \mathrm{kg}^{-1}$, when the average concentration of $\mathrm{Cu}$ in the soil was $38.8 \pm 6 \mathrm{mg} / \mathrm{kg}$. It is known that an organic substance of peat firmly holds heavy metals in the root layer of soil. Therefore sod-podzol soils, where the use of local peat of 100-200 tons per 1 hectare was widely used, concentrated Cd in 2.5 times and $\mathrm{Pb}$ in 2 times more than the regional background. On average, the elements in this soil made a decreasing series: Mn $>\mathrm{Pb}=\mathrm{Cu}=\mathrm{Vo}>\mathrm{Cd}$. On average, the contamination is characterized by a low level. In the study of samples of polygons with black soils and gray forest heavy loamy soils, abnormally increased accumulation of $\mathrm{Pb} 37.0 \pm 8 \mathrm{mg} / \mathrm{kg}$ was detected, and at some individual points it was $50 \mathrm{mg} \cdot \mathrm{kg}^{-1}$. On average, technogenic element Cd was accumulated in the forest steppe and steppe soils at the level of low pollution. The higher accumulation was detected in individual polygons - 0.38 $\pm 0.09-0.39 \pm 0.14 \mathrm{mg} \cdot \mathrm{kg}^{-1}$. Soil contamination $\mathrm{V}$ was detected of up to $240 \pm 51-253 \pm 60 \mathrm{mg} \cdot \mathrm{kg}^{-1}$. This element gets 
into pedosphere from burning coal, fuel oil in local boiler houses and Ryazan GRES power plant. Elements contaminants made a series for the grey forest soils: $\mathrm{Pb}=\mathrm{Cu}=\mathrm{V}>\mathrm{Mn}>\mathrm{Cd}$; for black soils: $\mathrm{V}>\mathrm{Cu}=\mathrm{Cd}>\mathrm{Pb}=\mathrm{Zn}=\mathrm{Mn}$.

The studied sod-podzol soil, in whose granulometric composition physical sand predominates, has weak ecological functions. It has shallow humus $(20-39 \mathrm{~cm})$, low capacity illuvial $(17-30 \mathrm{~cm})$ horizons and closely spaced glei horizons. Podzolized black soil with a heavy granulometric composition has a high buffering capacity. Prior to carrying out experiments, background lime treatment was carried out, and soils had reaction close to neutral $\mathrm{pH}>6.0$. The humus content was approximately $2 \%$ in the sod-podzol soil and about $4 \%$ in black soil. Provision of mobile phosphorus and potassium was defined as an average and increased.

The experiment at excessively contaminated black soil was slightly different. The organic system is represented by manure of cattle at a dose of $100 \mathrm{t} \cdot \mathrm{ha}^{-1}$ (field No. 2). Organic and mineral - against the backdrop of H100, a complete mineral fertilizer (N1P1K1, field No. 3) was annually applied. In the fields No. 4 and No. 5 periodic doses of phosphorus P2, P4 were studied. In the field No. 6 annual dose P120(e) was applied. In the last three fields mineral fertilizers N1K1 were annually applied. At the level of studied crop rotation all agrochemical methods of detoxification had a positive regularity At the same time, high efficiency of $109 \%$ was obtained from the use of organic and mineral system (field No. 3). Application of manure $40 \mathrm{t} \cdot \mathrm{ha}^{-1}$, and the simultaneous reserve use of $\mathrm{P} 240$ in the form of superphosphate (field No. 4) ensured maximum productivity, increase was $43.9 \mathrm{cnt} \cdot \mathrm{ha}^{-1}$ fodder units $(249 \%)$. Other fertilizer systems provided crop rotation productivity increase in $21.2-27 \mathrm{~kg} \cdot \mathrm{ha}^{-1}$ fodder units $(120-153 \%$, table 1$)$.

Table 1. Influence of fertilizers on efficiency of systems polluted with heavy metals sod-podzolic soil, cnt $\cdot$ ha $^{-1}$

\begin{tabular}{|l|c|c|c|c|c|c|c|}
\hline \multirow{2}{*}{$\begin{array}{c}\text { Field } \\
\text { No. }\end{array}$} & Potatoes (tubers) & Barley (grain) & Clover hay & Clover hay & $\begin{array}{c}\text { Biomass rye }+ \\
\text { barley }\end{array}$ & $\begin{array}{c}\text { Beetroot fodder } \\
\text { (roots) }\end{array}$ & $\begin{array}{c}\text { Oats } \\
\text { (grains) }\end{array}$ \\
\cline { 2 - 9 } & 2002 & 2003 & 2004 & 2005 & 2006 & 2007 & 2008 \\
\hline 1. & 29.7 & 29.0 & 8.1 & 8.3 & 12.2 & 14.2 & 21.7 \\
\hline 2. & 67.8 & 48.6 & 25.3 & 12.3 & 44.4 & 44.12 & 67.9 \\
\hline 3. & 75.9 & 54.0 & 25.9 & 10.8 & 46.2 & 52.8 & 67.4 \\
\hline 4. & 88.8 & 65.2 & 47.2 & 20.8 & 71.2 & 56.0 & 81.2 \\
\hline 5. & 75.6 & 39.6 & 30.1 & 11.2 & 30.6 & 36.0 & 71.0 \\
\hline 6. & 56.8 & 57.7 & 21.3 & 13.6 & 40.0 & 44.8 & 37.2 \\
\hline
\end{tabular}

Humification plays a significant role in the formation of soil, its most important properties and characteristics. The saturation of 1 hectare of sown area with organic was slightly different in the experiments, but the intensity of accumulation of humus from the various agrochemical means did not almost differ. These increases settled in the black soil in 6-25\% in the sod-podzol soil in 6-28\%. In the sod-podzol soil, humification process took place more intensively with a reserve the application of R480 against the backdrop of $\mathrm{N} 1 \mathrm{~K} 1$. Almost the same effect was demonstrated by organic (N80) and organomineral (H40 P240 N1K1) systems. The process of humification is determined by factors of soil formation, and fractional composition of humus is determined by the mineralogical composition. HA allowed to reveal that the most valuable HA-2 connected with calcium increased only in black soil under the influence of fertilizing systems. In the sod-podzol soil the concentration of HA of the first and third fraction increases. They were appreciably affected by fields of R480, H40 against the backdrop of N1K1. Comparing the fertilizers systems influence on the quality of humus in contaminated soils, fertilizers in black soil increase the content of HA in the 10-45 \%, FA - in 8-51\%, in the sodpodzol they increase the concentration of HA in the 19-42\%, FA remains unchanged. The problem of adaptation of plants in the conditions of technogenic environment is of primary importance. Plants have three biobarera against the admission of toxicants, these are the soil - the root - the stem - the reproductive organs. Effective phytoextraction depends mainly on the plant itself and the interaction of plant roots with bacteria and on the bioavailability of heavy metals in the soils. Although the accumulation of metals by plants can be enhanced by chemical chelates (Do Nascimento et al., 2006), these expensive compounds can increase the metal leaching risk and negative effects on soil fertility or soil structure (Khan et al., 2000; Kos and Lestan, 2003). Grain in contaminated soil is environmentally hazardous as the content of $\mathrm{Pb}$ is indicated at the level of $0.68,1.17 \mathrm{mg} \cdot \mathrm{kg}^{-1}$ (MPC 0.5), $\mathrm{Cd}-0.27,0.11 \mathrm{mg} \cdot \mathrm{kg}^{-1}$ (MPC 0.1), Zn - 76 (50 MPC). Use of fertilizing systems had a mostly positive effect, but products do not always become environmentally friendly (Table 2 ).

Table 2. Influence of fertilizers on efficiency of systems polluted black soil

\begin{tabular}{|c|c|c|c|c|c|}
\hline \multirow{3}{*}{ Field. No. } & \multicolumn{3}{|c|}{ Harvest of main products, $\mathrm{cnt} \cdot \mathrm{ha}^{-1}$} & \multicolumn{2}{|c|}{ Feed unit, cnt $\cdot$ ha $^{-1}$} \\
\hline & Barley & Beetroot fodder & Oats & Average productivity & Increase \\
\hline & 2006 & 2007 & 2008 & $2006-2008$ & \\
\hline 1. & 15.7 & 293 & 22.2 & 73.1 & - \\
\hline 2. & 32.1 & 573 & 27.7 & 128.6 & 55.5 \\
\hline 3. & 36.9 & 675 & 34.6 & 152.5 & 79.4 \\
\hline 4. & 24.2 & 375 & 34.0 & 103.2 & 30.1 \\
\hline 5. & 30.8 & 333 & 27.2 & 98.0 & 27.9 \\
\hline 6. & 26.5 & 452 & 34.7 & 115.4 & 42.3 \\
\hline $\mathrm{LSD}_{0.95}$ & 4.8 & 39.6 & 3.6 & - & - \\
\hline
\end{tabular}

Chun-yu et al. (2008) results show that heavy metal-solubilizing and plant growth promoting bacteria are important for plant growth and heavy metal uptake which may provide a new microbial enhanced-phytoremediation of metal- 
polluted soils. Increase in tissue $\mathrm{Pb}$ and $\mathrm{Cd}$ contents varied from $38 \%$ to $192 \%$ and from $5 \%$ to $191 \%$ in inoculated plants growing in heavy metal-contaminated soils compared to the uninoculated control, respectively. The overall contamination of soil by pollutants is characterized by the total content of HM. The negative impact of high concentrations of $\mathrm{HM}$ on the biosphere depends on their mobility. As long as the elements are strongly linked to the component parts of the soil, they are of difficult access to the plants; their migration in the biosphere is poorly expressed. In excessively contaminated soils (field No. 1) apparent dependence of HM on the soil type appears. In the sod-podzol soil concentration of ammonium acetate forms of $\mathrm{Pb}$ and $\mathrm{Cd}$ is less in the fields without fertilizers, of $\mathrm{Zn}$ and $\mathrm{Cu}$ - it is more in comparison with black soil. Considering the rate of movable element forms formation, it should be noted that $\mathrm{Cd}$ passed into the mobile form the most intensively in the black soil, but P120(e), against the backdrop of N1K1, sharply reduced this process. In the sod-podzol soil, field No. 6 had the same tendency (table 3).

Table 3. The average content of mobile forms of heavy metals in soils (extracting-ammonium acetate buffer $\mathrm{pH} 4.8$ )

\begin{tabular}{|c|c|c|c|c|c|c|c|c|}
\hline \multirow{2}{*}{ Field No. } & \multicolumn{3}{|c|}{ Podzolized black soil, $\mathrm{mg} \cdot \mathrm{kg}^{-1}$} & \multicolumn{3}{c|}{ Sod-podzol sandy loam soil, $\mathrm{mg} \cdot \mathrm{kg}^{-1}$} \\
\cline { 2 - 10 } & $\mathrm{Pb}$ & $\mathrm{Cd}$ & $\mathrm{Zn}$ & $\mathrm{Cu}$ & $\mathrm{Pb}$ & $\mathrm{Cd}$ & $\mathrm{Zn}$ & $\mathrm{Cu}$ \\
\hline \multirow{3}{*}{1.} & 19.2 & 0.25 & 53.6 & 33.2 & 24.1 & 0.44 & 37.1 & 14.3 \\
\cline { 2 - 10 } & 40 & 42 & 49 & 37 & 54 & 73 & 34 & 17 \\
\hline \multirow{2}{*}{2.} & 23.4 & 0.25 & 68.1 & 39.1 & 15.5 & 0.35 & 26.5 & 10.1 \\
\cline { 2 - 10 } & 59 & 42 & 62 & 43 & 39 & 58 & 24 & 11 \\
\hline \multirow{2}{*}{3.} & 20.9 & 0.26 & 65.4 & 37.6 & 10.2 & 0.35 & 29.3 & 8.5 \\
\cline { 2 - 10 } & 52 & 43 & 59 & 34 & 26 & 58 & 27 & 9 \\
\hline \multirow{2}{*}{4.} & 21.0 & 0.26 & 73.7 & 42.1 & 10.3 & 0.33 & 40.1 & 11.2 \\
\cline { 2 - 10 } & 53 & 43 & 67 & 47 & 26 & 55 & 36 & 12 \\
\hline \multirow{2}{*}{5.} & 20.7 & 0.23 & 72.9 & 37.6 & 8.6 & 0.34 & 59.3 & 9.6 \\
\cline { 2 - 10 } & 52 & 38 & 66 & 34 & 22 & 57 & 54 & 11 \\
\hline \multirow{2}{*}{6.} & 19.0 & 0.24 & 67.4 & 38.0 & 13.7 & 0.23 & 48.3 & 7.8 \\
\hline & 48 & 40 & 61 & 42 & 34 & 38 & 44 & 7 \\
\hline LSD $_{0.95}$ & 3.4 & 0.06 & 10.0 & 6.9 & 3.8 & 0.1 & 12.1 & 4.2 \\
\hline
\end{tabular}

The identified dispersion routes can be related mainly to the geomorphologic and climatic characteristics of the site, as well as to the ore and mine waste mineralogy, but also to a consequence of the lack of control and remediation measures during and after mining operations. Statistical relationship of $\mathrm{As}, \mathrm{Pb}, \mathrm{Cu}$ and $\mathrm{Zn}$ in soil and sediment obtained by $\mathrm{PCA}$, confirm that the source of these elements can be related directly to mining activities in the area. Thus, under the climatic conditions of the site the dispersion of the contaminants in sediment and soil seems to respond in a greater degree to a physical dispersion of mineral particles from tailings impoundments than a chemical mobility of pollutants (Razo et al., 2004). The migration ability of HM depends on a set of soil properties, chemical contaminants, landscape environment. Their infiltration through the soil profile is accompanied by excretion of organic substance and its related metals. The studied fertilizer systems in the sod-podzol soil mainly decrease the removal of $\mathrm{Pb}, \mathrm{Zn}, \mathrm{Cu}$ beyond the soil profile and increase the $\mathrm{Cd}$. In the black soil, fertilizers increased the migration of $\mathrm{Pb}$ and reduced $\mathrm{Cd}$. Correlation studies on the impact of the quality of humus (groups, fractions) on the content of $\mathrm{HM}$ in intrasoil waters showed that the migration of $\mathrm{Pb}$ in soil and ground waters is mainly due to the 3rd fraction of HA in the sod-podzol soil $(r=0.59)$ and FA-3 - in black soil $(r=0.69)$. Receipt of Cd into the lysimeter waters with FA-3 in the sod-podzol soil has a high level of dependence $(\mathrm{r}=0.77)$. In the black soil FA group, of HA-2, HA-3 fractions and the sum of HA fractions had negative correlations $(\mathrm{r}=-0.75,-0.78,-0.57,-0.74)$. But in this soil the high migration capacity of Cd with HA-1 faction $(r=0.81)$ was found. Cu migrates mainly in the form of complex compounds in HA-2 and FA-2 fractions in the sod-podzol soil. Migration capacity of Zn to a greater extent is found in black soil in the form of FA-3 $(r=0.83)$ and HA-2 $(r=0.65)$ fractions.

Heavy metal contamination of soils through anthropogenic activities is a widespread and serious problem confronting scientists and regulators throughout the world. Total heavy metal contents ranged from 5271 to $16369 \mathrm{mg} / \mathrm{kg}$ for $\mathrm{Pb}, 387$ to $1221 \mathrm{mg} \cdot \mathrm{kg}^{-1}$ for Zn, 3.0 to $9.3 \mathrm{mg} \cdot \mathrm{kg}^{-1}$ for $\mathrm{Cd}$ and 65 to $206 \mathrm{mg} \cdot \mathrm{kg}^{-1}$ for Cu in Shaoxing, Zhejiang, China. Strongly significant relationships between $\mathrm{H}_{2} \mathrm{O}-\mathrm{Pb}, \mathrm{H} 2 \mathrm{O}-\mathrm{Zn}$ and $\mathrm{H}_{2} \mathrm{O}-\mathrm{Cu}$, strong positive correlations between $\mathrm{H} 2 \mathrm{O}-\mathrm{Pb}$, $\mathrm{H}_{2} \mathrm{O}-\mathrm{Zn}, \mathrm{H}_{2} \mathrm{O}-\mathrm{Cu}$ and organic matter in soil were found. The content of $\mathrm{H}_{2} \mathrm{O}-\mathrm{Pb}, \mathrm{H}_{2} \mathrm{O}-\mathrm{Zn}, \mathrm{H}_{2} \mathrm{O}-\mathrm{Cu}$ was negatively correlated with $\mathrm{pH}$ values. The similar negative relationships between $\mathrm{pH}$ values and exchangeable heavy metals were also recorded. It is suggested that increasing soil $\mathrm{pH}$ or liming the soil could decrease bioavailability of heavy metals in the soil (Li et al., 2005).

\section{CONCLUSION}

1. In the Ryazan region, the greatest atmospheric technogenic arrival relates to the lead.

2. Soil and ecological monitoring indicated that the intensity of soil contamination with HM is due to the proximity of industrial enterprises. In general, there is a low, medium soil contamination. Although there are points of monitoring, which define increased and high levels of contamination with $\mathrm{Pb}, \mathrm{V}, \mathrm{Cu}, \mathrm{Cd}$.

3. During detoxification of increased level of contamination with the metal complex $(\mathrm{Cd}, \mathrm{Pb}, \mathrm{Zn}, \mathrm{Cu})$ the most effective organomineral fertilizer system was revealed. 
4. Systems of fertilizers mainly decrease the removal of $\mathrm{Pb}, \mathrm{Zn}, \mathrm{Cu}$ beyond the soil profile in the sod-podzol soil, but they increase $\mathrm{Cd}$. In black soil, the migration of $\mathrm{Cd}$ was reduced, but $\mathrm{Pb}$ was increased. Migration is attributable primarily to fulvic acids.

\section{REFERENCES}

1. Abou-Shanab, R. A. I., Angle, J. S., Delorme, T. A., Chaney, R. L., van Berkum, P., Moawad, H., Ghanem, K., Ghozlan, H. A., 2003. Rhizobacterial effects on nickel extraction from soil and uptake by Alyssum murale. New Phytologist, Vol. 158, Iss. 1, pp. 219-224. http://dx.doi.org/10.1046/j.1469-8137.2003.00721.x

2. Bolan, N. S., Adriano, D. C., Mahimairaja, S. 2004. Distribution and bioavailability of trace elements in livestock and poultry manure byproducts. Critical Reviews in Environmental Science and Technology, Vol. 34, Iss. 3, pp. $291-338$. http://dx.doi.org/10.1080/10643380490434128

3. Caracciolo A. B., Bottoni P., Grenni P. 2013. Microcosm studies to evaluate microbial potential to degrade pollutants in soil and water ecosystems. Microchemical Journal, Vol. 107, pp. 126-130. http://dx.doi.org/10.1016/j.microc.2012.05.022

4. Cerri, C. E. P., Sparovek, G., Bernoux, M., Easterling, W. E., Melillo, J. M., Cerri, C. C. 2007. Tropical agriculture and global warming: impacts and mitigation fields. Scientia Agricola, Vol. 64, No. 1, pp. 83-99. http://dx.doi.org/10.1590/S0103-90162007000100013

5. Chun-Yu, J., Xia-Fang, S., Qian, M., Qing-Ya, W. 2008. Isolation and characterization of a heavy metal-resistantBurkholderia sp. from heavy metal-contaminated paddy field soil and its potential in promoting plant growth and heavy metal accumulation in metalpolluted soil. Chemosphere, Vol. 72, Iss. 2, pp. 157-164. http://dx.doi.org/10.1016/j.chemosphere.2008.02.006

6. Do Nascimento, C. W. A., Amarasiriwardena, D., Xing, B. S., 2006. Comparison of natural organic acids and synthetic chelates at enhancing phytoextraction of metals from a multi-metal contaminated soil. Environmental Pollution, Vol. 140, Iss. 1, pp.114-123. http://dx.doi.org/10.1016/i.envpol.2005.06.017

7. Evtyuhin, V. 2011. Environmental substantiation of control and detoxification of agrocenoses of the south of the central Nechernozemye, subject to technogenic influence / Thesis for candidate for Doctor of Biological Sciences. Balashikha.

8. Glazovskaya, M. 1998. Geochemistry of natural and technogenic landscapes of the USSR. Moskau.: Visshaya Shkola.

9. Idris, R., Trifonova, R., Puschenreiter, M., Wenzel, W. W., Sessitsch, A., 2004. Bacterial communities associated with flowering plants of the Ni hyperaccumulator Thaspi goesingense. Applied and Environmental Microbiology, Vol. 70, No. 5, pp. $2667-2677$. http://dx.doi.org/10.1128/AEM.70.5.2667-2677.2004

10. Janos, P., Vavrova, J., Herzogova, L., Pilarova, V. 2010. Effects of inorganic and organic amendments on the mobility (leachability) of heavy metals in contaminated soil: a sequential extraction study. Geoderma, Vol. 159, Iss. 3-4, pp. 335-341. http://dx.doi.org/10.1016/j.geoderma.2010.08.009

11. Khan, A. G., Kuek, C., Chaudhry, T. M., Khoo, C. S., Hayes, W. J., 2000. Role of plants, mycorrhizae and phytochelators in heavy metal contaminated land remediation. Chemosphere, Vol. 41, Iss. 1-2, pp. 197-207. http://dx.doi.org/10.1016/S0045-6535(99)00412-9

12. Kobak, K. I., Kondrasheva, N. Yu., Turchinovich, I. E. 1998. Changes in Carbon Pools of Peatland and Forests in Northwestern Russia During the Holocene. Global and Planetary Change, Vol. 16-17, pp. 75-84. http://dx.doi.org/10.1016/S0921-8181(98)00011-3

13. Kos, B., Lestan, D., 2003. Induced phytoextraction/soil washing of lead using biodegradable chelate and permeable barriers. Environmental Science \& Technology, Vol. 37, Iss. 3, pp. 624-629. http://dx.doi.org/10.1021/es0200793

14. Li, J, Xie, Z. M., Zhu, Y., G., Naidu, R. 2005. Risk assessment of heavy metal contaminated soil in the vicinity of a lead/zinc mine. Journal of Environmental Sciences (China), Vol. 17, Iss. 6, pp. 881-885.

15. Mazhaysky, Y. 2002. Substantiation of regimes of complex amelioration in the conditions of technogenic contamination of agrolandscape / Thesis for candidate for Doctor of Agricultural Sciences. - Moskau.

16. Mclaughlin, M. J., Parker, D. R., Clarke, J. M., 1999. Metals and micronutrients-food safety issues. Field Crops Research, Vol. 60, Iss. 1-2, pp. 143-163. http://dx.doi.org/10.1016/S0378-4290(98)00137-3

17. Mench, M., Lepp, N., Bert V., Schwitzguébel, J. P., Gawronski, S. W. Schoder, P., Vangronsveld ,J. 2010. Successes and limitations of phytotechnologies at field scale: outcomes, assessment and Outlook from COST action 859. Journal of Soils and Sediments, Vol. 10, Iss. 6, pp. 1039-1070. http://dx.doi.org/10.1007/s11368-010-0190-x

18. Neustadt, M. I. 1984. Holocene Peatland Development, in Late Quaternary Environments of the Soviet Union, Ed. A. Velichko, Minneapolis: University of Minnesota Press, pp. 201-206.

19. Ovcharenko, M. 1997. Heavy metals in the system "Soil - plant - fertilizer", Moskva.

20. Razo, I., Carrizales, L., Castro, J., Diaz-az-Barriga, F., Monroy M. 2004. Arsenic and Heavy Metal Pollution of Soil, Water and Sediments in a Semi-Arid Climate Mining Area in Mexico. Water, Air, and Soil Pollution, Vol. 152, Issue 1, pp. $129-152$. http://dx.doi.org/10.1023/B:WATE.0000015350.14520.c1

21. Saha R., Chaudhary R. S., Somasundaram J. 2012. Soil Health Management under Hill Agroecosystem of North East India. Applied and Environmental Soil Science, Article ID 696174, pp. 1-9.

22. Sheng, X. F., Xia, J. J., 2006. Improvement of rape (Brassica napus) plant growth and cadmium uptake by cadmium-resistant bacteria. Chemosphere, Vol. 64, Iss. 6, pp. 1036-1042. http://dx.doi.org/10.1016/j.chemosphere.2006.01.051

23. Smalla, K., Wieland, G., Buchner, A., Zock, A., Parzy, J., Kaiser, S., Roskot, N., Heuer, H., Berg, G., 2001. Bulk and rhizosphere soil bacterial communities studied by denaturing gradient gel electrophoresis: plant-dependent enrichment and seasonal shifts revealed. Applied and Environmental Microbiology, Vol. 67, No. 10, pp. 4742-4751. http://dx.doi.org/10.1128/AEM.67.10.4742-4751.2001

24. Tordoff, G. M., Baker, A. J. M., Willis, A. J. 2000. Current approaches to the revegetation and reclamation of metalliferous mine wastes. Chemosphere, Vol. 41, Iss. 1-2, pp. 219-228. http://dx.doi.org/10.1016/S0045-6535(99)00414-2 
25. Venny, Suyin, G., Hoon, K. Ng. 2012 Current status and prospects of Fenton oxidation for the decontamination of persistent organic pollutants (POPs) in soils. Chemical Engineering Journal, Vol. 213, pp. 295-317. http://dx.doi.org/10.1016/j.cej.2012.10.005

26. Zhang, X., Wang, H, He, L., Lu, K., Sarmah, A., Li, J., Bolan, N. S., Pei, J., Huang, H. 2013. Using biochar for remediation of soils contaminated with heavy metals and organic pollutants. Environmental Pollution And Risk Assessments, Vol. 20, Iss. 12, pp. $8472-8483$. http://dx.doi.org/10.1007/s11356-013-1659-0 